\title{
Advanced Gasification-Based Fuel Conversion and Electric Energy Production System
}

\author{
Quarterly Technical Progress Report - Phase I
}

\section{REPORTING PERIOD:}

From: January 1, 2003

To: $\quad$ March 31, 2003

PRINCIPAL AUTHORS:

Joseph Rabovitser, GTI

Bruce Bryan, GTI

April 2003

COOPERATIVE AGREEMENT:

DE-FC26-01NT41108

\section{SUBMITTING ORGANIZATION:}

Gas Technology Institute

1700 South Mount Prospect Road

Des Plaines, IL 60018-1804 


\section{DISCLAIMER}

This report was prepared as an account of work sponsored by an agency of the United States Government. Neither the Unites States Government nor any agency thereof, nor any of their employees, makes any warranty, express or implied, or assumes any legal liability or responsibility for the accuracy, completeness, or usefulness of any information, apparatus, product, or process disclosed, or represents that its use would not infringe privately owned rights. Reference herein to any specific commercial product, process, or service by trade name, trademark, manufacturer, or otherwise does not necessarily constitute or imply its endorsement, recommendation, or favoring by the United States Government or any agency thereof. The views and opinions of authors expressed herein do not necessarily state or reflect those of the United States Government or any agency thereof. 


\begin{abstract}
The objective of this project is the development and commercial demonstration of an advanced biomass gasification-based power generation system at Boise Cascade Corporation's pulp and paper mill in DeRidder, Louisiana. The advanced power generation system is intended to meet the immediate needs of the forest products industry for highly efficient and environmentally friendly electricity and steam generation systems utilizing existing wood waste as the primary fuel resource. The novel system is based on three advanced technology components: GTI's RENUGAS $^{\circledR}$ and 3-stage solid fuels combustion technologies coupled with one of the power generation approaches used in DOE's HIPPS program.
\end{abstract}

The project will be conducted by the Gas Technology Institute (GTI) and Boise Paper Solutions (Boise), the paper making division of Boise Cascade. The project team includes Babcock Borsig Power (BBP), Solar Turbines Inc., Carbona Corporation, the University of North Dakota Energy and Environmental Research Center (EERC), and Nexant LLC, a Bechtel technology and consulting company.

Phase 1 of the project is a technical and economic evaluation of the system at the DeRidder site. A Continuation Application will be submitted at the conclusion of Phase 1 for authorization to proceed to testing and design in Phase 2. Phase 2 includes pilot-scale verification of selected system components and preparation of a detailed engineering design and cost estimate for retrofit of the advanced power system at the DeRidder mill. Phase 3 will complete procurement and construction of the system at the DeRidder site along with all required permitting activities. Phase 4 of the project will included plant commissioning, startup and demonstration operations.

Design information for the Gasification Island was completed during the quarter. Two vendor quotations were received for the bark/hog fuel dryers. A final layout plan for the major equipment was developed and submitted to DeRidder for review and approval.

The Institute of Paper Science and Technology (IPST) completed a subcontract for a laboratory study on VOC emissions from wood waste drying using bark from the DeRidder mill. Samples of DeRidder's lime mud and green liquor dregs were collected and analyzed in GTI's laboratory. It was determined that lime mud is far too fine to be utilized as inert bed material in the fluidized bed gasifier. Results for the green liquor dregs are currently being reviewed.

Design analysis for the in-furnace HPHT Air Heater was completed and the external Syngas Cooler/Air Heater was begun. Materials were received for the air heater tube testing system to be installed in Boiler No. 2 at DeRidder. A refractory interference problem with the original testing system design was discovered and resolved.

Analyses of the externally recuperated gas turbine cycles (air heater and booster combustor in parallel or series) were continued including the effects of steam cooling and inlet air humidification on power output and operating cost. Discussions were continued with turbine manufacturers regarding the technical, time and cost requirements for developing an externally recuperated turbine engine suitable for use in the project.

A 5-month no-cost time extension was requested and received for the project to accommodate design and evaluation of externally recuperated gas turbines using HPHT air as the working fluid. 


\section{TABLE OF CONTENTS}

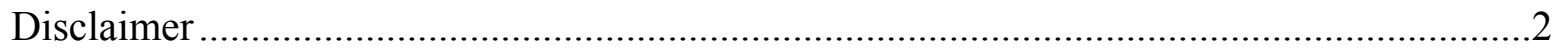

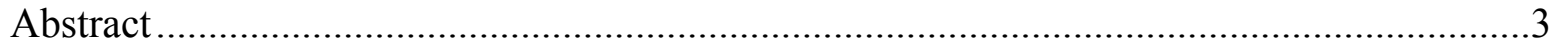

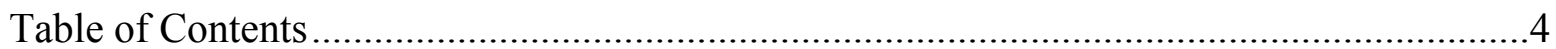

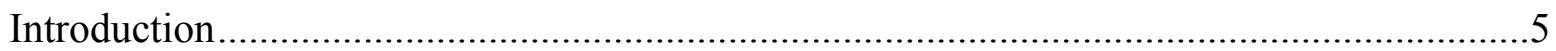



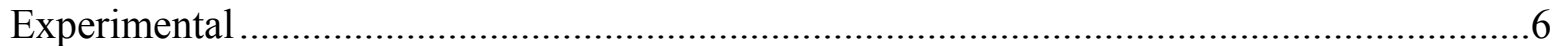

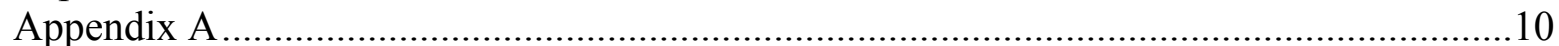

\section{List of Graphical Materials}

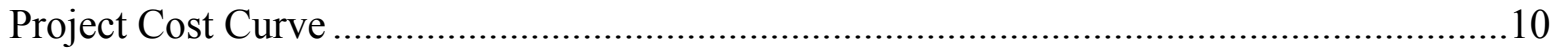

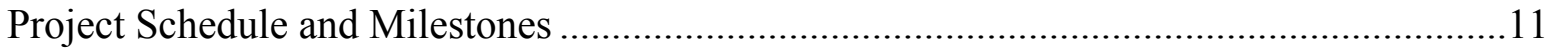




\section{INTRODUCTION}

Boise Paper Solutions and the Gas Technology Institute (GTI) are cooperating to develop, demonstrate and place in continuous operation an advanced biomass gasification-based power generation system suitable for near-term commercial deployment in the Forest Products Industry. The system will be used in conjunction with, rather than in place of, existing wood waste fired boilers and flue gas cleanup systems. The novel system will include three advanced technological components based on GTI's RENUGAS ${ }^{\circledR}$ and three-stage stoker combustion technologies, and a gas turbine-based power generation concept developed in DOE's High Performance Power System (HIPPS) program. The system has, as its objective, to avoid the major hurdles of high-pressure gasification, i.e., high-pressure fuel feeding and ash removal, and hot gas cleaning that are typical for conventional IGCC power generation. It aims to also minimize capital intensity and technology risks. The system is intended to meet the immediate needs of the forest products industry for highly efficient and environmentally friendly electricity and steam generation systems utilizing existing wood waste as fuel resources.

\section{EXECUTIVE SUMMARY}

Project Objective: The overall objective of this project is to demonstrate the commercial feasibility of an advanced biomass gasification-based power generation system at the Boise Paper Solutions' pulp and paper mill at DeRidder, Louisiana.

Background: The project team, led by GTI, will develop, design, install, demonstrate and place in continuous commercial operation an advanced biomass gasification-based power generation system including gasification, syngas reburning and indirect high temperature air heating technology and utilizing existing wood waste resources as fuel. The system will be integrated with existing powerhouse equipment, including the wood waste-fired stoker boiler and flue gas cleaning system, in a stepwise manner to insure the reliability of steam and power generation. Staged implementation will reduce technology risk, improve operator acceptance and allow energy, environmental and economic benefits to begin to be realized by the mill early in the project.

The project will be conducted in four phases over a period of 6 years. The phases are structured to provide a logical path to verify the technical and economic feasibility of the proposed biomass gasification-based power generation approach in Phase 1, with a Continuation Decision point prior to proceeding with pilot testing and detailed design. A detailed engineering design and cost estimate will be developed in Phase 2 with another Continuation Decision point prior to proceeding to Phase 3. Construction and demonstration of the system will be completed in Phases 3 and 4.

Boise's pulp and paper mill in DeRidder, Louisiana agreed to be the host site for the project, completing a major milestone ahead of schedule and allowing the design to center on the specific requirements of the host site early in the project.

The power system configuration was refined to better meet the specific energy requirements and constraints existing at the DeRidder mill. Changes from the original concept included the addition of an external syngas cooler/air heater to handle a portion of the air heating load and the addition of bark dryers to improve bark feeding and make more high level heat available for air heating in the bark boiler. The modified configuration was reviewed with DeRidder mill management, Boise Corporate Engineering and at the 2002 DOE/AF\&PA Agenda 2020 annual project review meeting. Four commercially available candidate tube materials for the high- 
pressure, high-temperature air heaters were selected and a design completed for material coupon test stands for the air heater tubes inside PB No. 2. Two gas turbine configurations for the Power Island Design Study were selected for further study from six configurations originally proposed and the turbine study was expanded to identify the best candidate engines for development and demonstration in subsequent phases of the project.

Status (March 31, 2002): The final report for the Gasification Island was completed during the quarter, including the bark/hog fuel dryers. A draft final report for the Power Island Design Study was received, reviewed and commented on. The final report for this study is expected shortly. A draft final report for the Indirect Air Heater System Design Study and Boiler Modification Design Study was received. The report covered the internal air heater design and cost but not the external air heater/syngas cooler. The final report for these studies, including the external air heater/syngas cooler, is pending. A draft report was received for the IPST laboratory study on VOC emissions from wood waste drying using bark from the DeRidder mill. Comments were returned to IPST and their final report is pending.

\section{Activities Next Quarter:}

- Complete the final Boiler Modification and Air Heater Design Reports

- Complete the Power Systems Integration and Capital and Operating Cost Reports

- Begin integration of all task reports into the final report for the project

Project Costs and Schedule: The project budget and milestone information is presented in Appendix A.

\section{EXPERIMENTAL}

\section{Project Tasks}

Task 0.0. NEPA Review

There were no activities in this task during the quarter.

Task 1.1. Demonstration Site Evaluations

The objective of this task was completed with the agreement by the DeRidder mill to be the host site for the advanced gasification-based power system demonstration.

Task 1.2. Gasification Island Design Study

The final task report for the Gasification Island was received during the quarter, including the bark/hog fuel dryers. An installed capital cost estimate for the Gasification Island was also received, and is summarized in Table 1 below.

A draft report was received for the IPST laboratory study on VOC emissions from wood waste drying using bark from the DeRidder mill. The VOC and HAP emissions during drying of fresh bark from the Boise, DeRidder mill were found to be consistent with levels previously reported in the literature. Comments were returned to IPST and their final report is pending.

Task 1.3. Indirect Air Heater System Design Study

Fabrication of the air heater tube testing assemblies was completed at ORNL including attachment and testing of thermocouples. The completed test assemblies are shown in Figures 1 and 2. The assemblies were transported to the DeRidder mill by ORNL personnel and installed through existing access doors on the West side of Level 2 and Level 5 on No. 2 Power Boiler on 
March 19, 2003. Identification of the tubes and their associated thermocouples and pressure transmitters is given in Table 2. below.

Table 1. Gasification Island Installed Capital Cost

\begin{tabular}{|c|c|}
\hline Cost Breakdown Structure & Cost, \$K \\
\hline 1.0 Gasification Plant & \\
\hline 1.1 Fuel Feeding System & $1,416.8$ \\
\hline 1.2 Limestone Feeding System & 194.0 \\
\hline 1.3 Gasification System & $1,957.3$ \\
\hline 1.4 Process Air System & 739.7 \\
\hline 1.5 Gas Cooling System & 587.9 \\
\hline 1.6 Flare System & 262.6 \\
\hline 1.7 Gasifier Ash Removal System & 286.7 \\
\hline 1.8 Gasification Plant Cooling Water System & 32.3 \\
\hline 1.9 Nitrogen Gas Generation \& Distribution System & 600.1 \\
\hline 7.1 Wet Wood Dryers (2) & $1,359.2$ \\
\hline Total Gasification Plant & $7,436.7$ \\
\hline
\end{tabular}

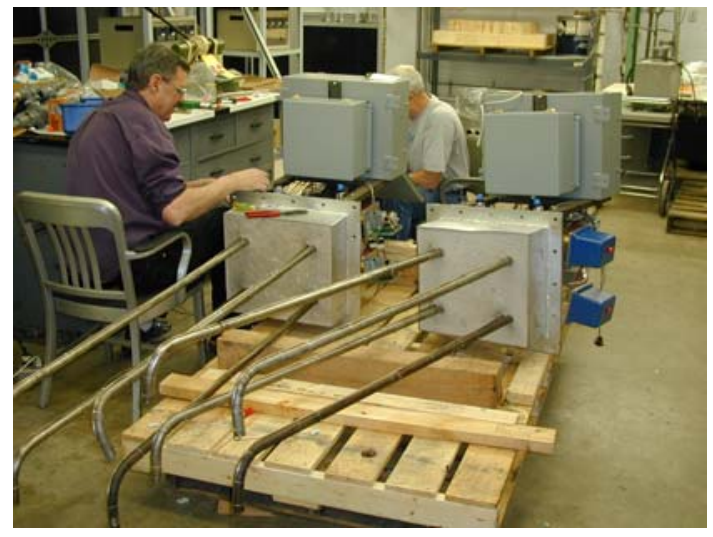

Figure 1. Air heater tube testing assemblies during final installation of instruments and controls

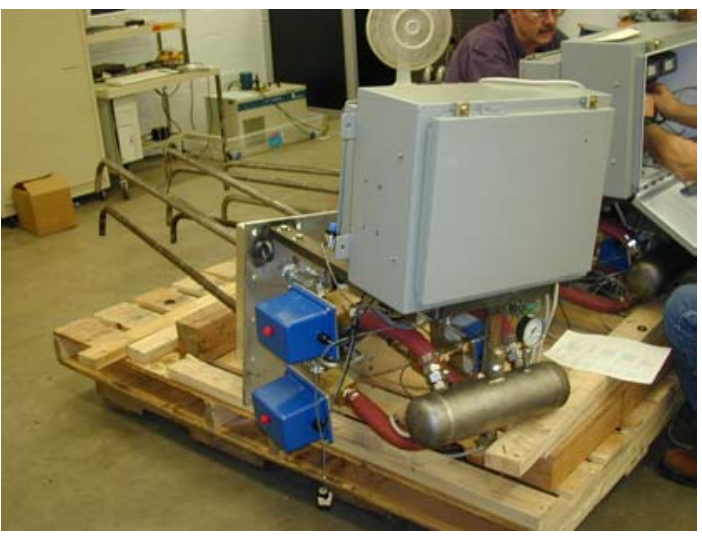

Figure 2. Furnace-side view of air heater tube testing assemblies

Table 2. Tube materials and their associated thermocouples and pressure transmitters in the Air Heater tube test assemblies at DeRidder, LA

\section{Lower Door}

\begin{tabular}{|c|c|c|c|c|}
\hline Tube \# & Material/Thk, in. & Skin T/C \# & Air T/C \# & Pressure \\
\hline 1 & $353 \mathrm{MA} / 0.12$ & $1,2,3,4$ & 5 & 1 \\
\hline 2 & $800 \mathrm{H} / 0.22$ & $6,7,8.9$ & 10 & 2 \\
\hline 3 & $\mathrm{P} 91 / 0.16$ & $11,12,13,14$ & 15 & 3 \\
\hline 4 & $347 \mathrm{H} / 0.22$ & $16,17,18,19$ & 20 & 4 \\
\hline
\end{tabular}

\section{Upper Door}

\begin{tabular}{|c|c|c|c|c|}
\hline Tube \# & Material/Thk, in. & Skin T/C \# & Air T/C \# & Pressure \\
\hline 5 & $353 \mathrm{MA} / 0.12$ & $21,22,23,24$ & 25 & 5 \\
\hline 6 & $347 \mathrm{H} / 0.22$ & $26,27,28,29$ & 30 & 6 \\
\hline 7 & $\mathrm{P} 91 / 0.16$ & $31,32,33,34$ & 35 & 7 \\
\hline 8 & $800 \mathrm{H} / 0.22$ & $36,37,38,39$ & 40 & 8 \\
\hline
\end{tabular}


Both test assemblies were installed with the airflow control valves wide open. The installed test assemblies are shown in Figures 3 and 4. Several concerns were noted regarding the positioning of the assemblies in the boiler. The upper assembly was mounted through an existing access door between the first and second superheater banks. This location may not reach a temperature high enough to be representative of the expected internal air heater environment. Also, this location is just below an existing traversing soot blower, and the force of the steam flow might damage the thermocouples and/or tubes. This was confirmed on the first activation of the soot blower, which bent the \#5 tube. The lower assembly was located more or less in the line of flight of bark from the west feed chute and might therefore also be subject to tube and/or thermocouple damage.

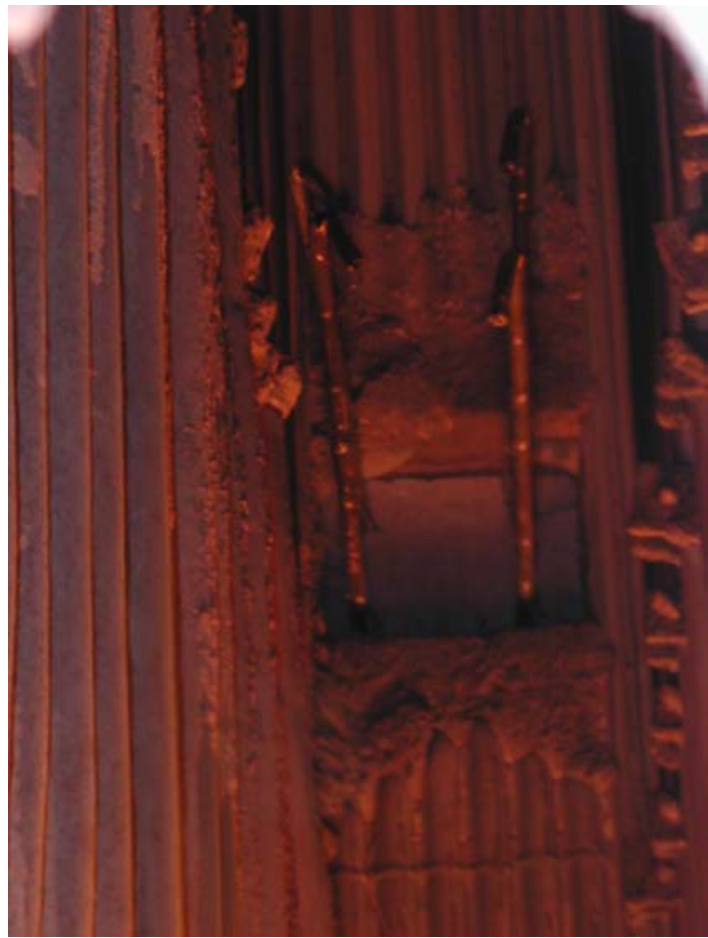

Figure 3. Air heater tube testing assembly installed in the upper

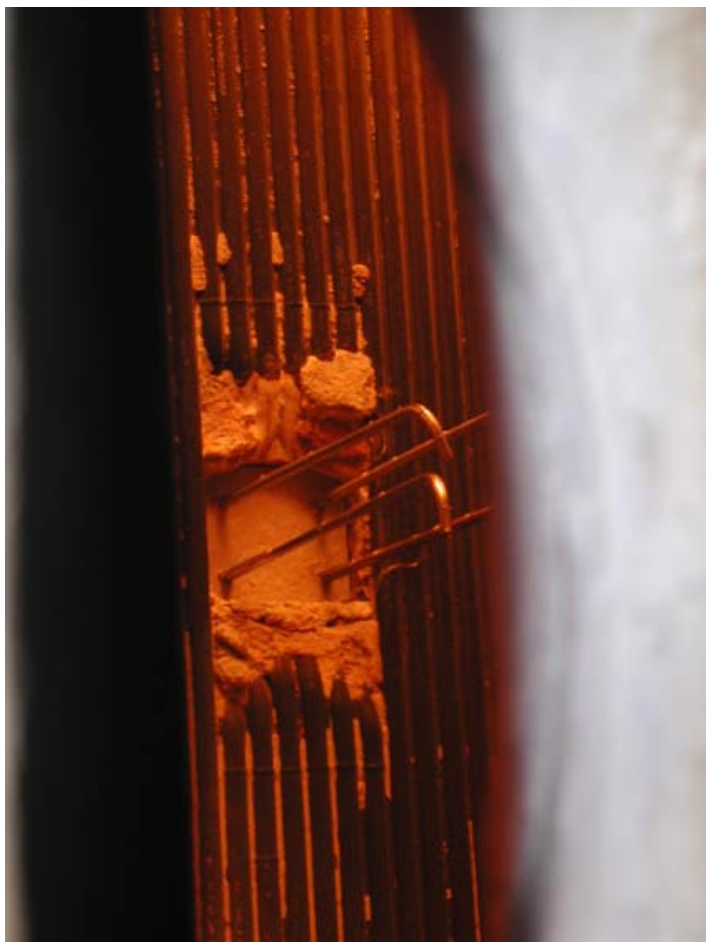

Figure 4. Air heater tube testing assembly installed in the lower

Initial Readings with the boiler at partial load and with the gas-fired cofiring burners on showed air supply pressures at the tube inlets ranging from $1.22-4.47$ psig. Exit air temperatures from the tubes varied from $600-735^{\circ} \mathrm{F}$ in the lower furnace and $344-397^{\circ} \mathrm{F}$ in the upper furnace. Initial skin temperatures on the outer surface of the tubes ranged from $850-1690^{\circ} \mathrm{F}$ in the lower furnace and $530-1105^{\circ} \mathrm{F}$ in the upper furnace. The lower temperatures in the upper furnace assembly reflect its location between the first and second superheater banks. 


\section{Task 1.4. Stoker Boiler Modification Study}

A Draft final task report was received for the Internal HPHT Air Heater and Stoker Boiler Modifications. A draft final task report for the External HPHT Air Heater between the gasifier and stoker boiler is to be issued separately.

Budget pricing for the Internal HPHT Air Heater was received at $\$ 2,500,000$. Pricing is delivered and erected, and based on today's dollars. The pricing breakdown is as follows;

Engineering, Drafting Field Service, \& Management $\$ \$ 70,000$

Materials and Fabrication $\$ \$ 1,280,000$

Instillation Labor base on $\$ 85.00 / \mathrm{Hr} \quad \$ 750,000$

Total Budget Pricing $\$ 2,500,000$

Task 1.5. Power Island Design Study

A draft final task report for the Power Island Design Study was received, reviewed and comments returned to the contractor. The approved final task report for this study is expected at the beginning of the next quarter.

Task 1.6. Power Systems Integration Study

There was no activity in this task during the quarter.

Task 1.7. Capital and Operating Cost Study

Installed capital cost information for the gasification section and dryers, the internal HPHT air heater and the required boiler modifications was forwarded to NEXANT for inclusion in the overall project estimate. Cost basis information for Operating and Maintenance costs for the gasification system and feed dryers was also forwarded to NEXANT.

Task 1.8. Phase 1 Project Management

GTI attended the IEA Annex XV meeting in Atlanta on Feb. 10-12 and presented a review of project status at the request of IEA and DOE

Work Planned for Next Quarter:

- Complete the final Boiler Modification and Air Heater Design Reports

- Complete the Power Systems Integration and Capital and Operating Cost Reports

- Begin integration of all task reports into the final report for the project 


\section{Appendix A}

Project Costs

\begin{tabular}{|c|c|c|c|c|c|c|c|}
\hline \multicolumn{2}{|c|}{$\begin{array}{l}\text { Project Budget } \\
\text { Period }\end{array}$} & \multicolumn{3}{|c|}{ Period } & \multicolumn{3}{|c|}{ Cumulative } \\
\hline From & To & $\mathrm{DOE}^{*}$ & Share & Total & DOE & Share & Total \\
\hline $1 / 1 / 03$ & $3 / 31 / 03$ & 146,979 & 29,059 & $\$ 176,038$ & 586,887 & 237,204 & 824,0 \\
\hline Pre & ous Total & $\$ 439,908$ & $\$ 208,145$ & $\$ 648,053$ & $71.2 \%$ & $28.8 \%$ & 100.0 \\
\hline
\end{tabular}

\section{Budget Data}

\begin{tabular}{|c|c|c|c|c|c|c|c|c|c|c|}
\hline \multirow{3}{*}{\begin{tabular}{|c|} 
GTI, Boise Cascade \\
FC26-01NT41108 \\
Project Budget \\
Periods
\end{tabular}} & \multicolumn{10}{|c|}{$\begin{array}{l}\text { Advanced Gasification-Based Fuel Conversion and Electric Energy Production System (1691) } \\
\text { Rabovitser }\end{array}$} \\
\hline & \multicolumn{6}{|c|}{ Approved } & \multicolumn{4}{|c|}{ DOE Obligated } \\
\hline & \multicolumn{3}{|c|}{ Incremental } & \multicolumn{3}{|c|}{ Cumulative } & Mod & Increm & Cumul & Date \\
\hline From & DOE & Share & Total & DOE & Share & Total & \multirow[t]{4}{*}{ A000 } & \multirow[t]{4}{*}{$1,028,010$} & \multirow[t]{4}{*}{$1,028,010$} & \multirow[t]{4}{*}{$8 / 8 / 2001$} \\
\hline $7 / 15 / 2001 \quad 8 / 31 / 2003$ & $1,028,010$ & 300,500 & $1,328,510$ & $1,028,010$ & 300,500 & $1,328,510$ & & & & \\
\hline $9 / 1 / 2003 \quad 11 / 30 / 2007$ & $25,965,065$ & $27,800,000$ & $53,765,065$ & $26,993,075$ & $28,100,500$ & $55,093,575$ & & & & \\
\hline Total & $26,993,075$ & $28,100,500$ & $55,093,575$ & $49.0 \%$ & $51.0 \%$ & $100.0 \%$ & & & & \\
\hline
\end{tabular}

Note: Only the first budget period has been approved. The second budget period is estimated.

\section{Cost Curve}

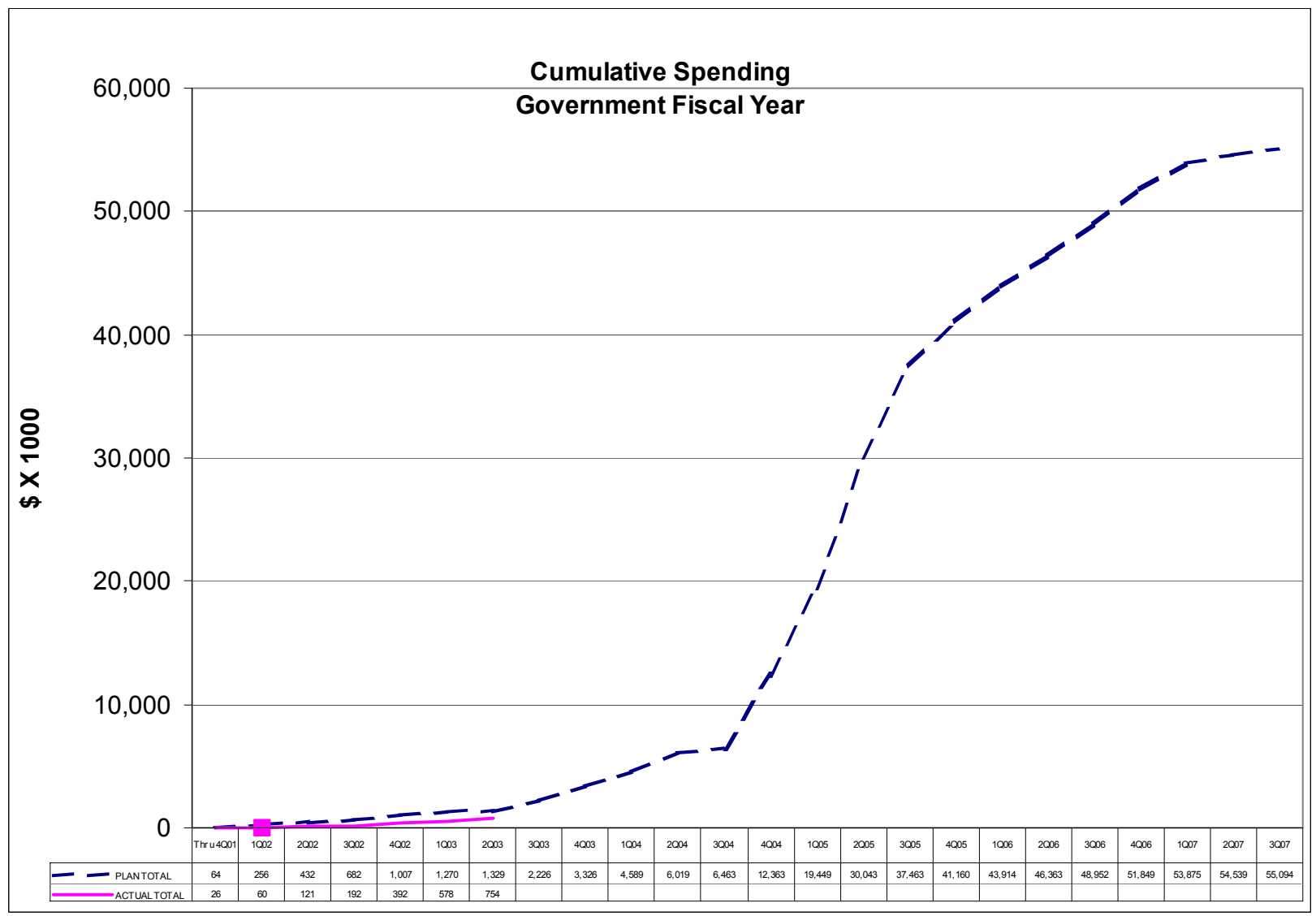




\section{Schedule and Milestones}

\begin{tabular}{|c|c|c|c|c|c|c|c|c|}
\hline Task Name & \begin{tabular}{|l|}
2001 \\
$M J|J| A S S O N D$
\end{tabular} & \begin{tabular}{|c|}
2002 \\
$J|F| M|M J| J|S| S|N| D J$
\end{tabular} & \begin{tabular}{|c|c|}
\multicolumn{2}{|c|}{2003} \\
$J|F| M||^{\prime} J|J| A|S| N \mid D$
\end{tabular} & \begin{tabular}{|c|}
2004 \\
$J / F M / M|J| J|A S O| N D$
\end{tabular} & \begin{tabular}{|c|}
2005 \\
$J|F M| M J|J| A|S O| N D$
\end{tabular} & \begin{tabular}{|c|c|}
2006 \\
$|J| F|M A| M J J / A|S| S N D$
\end{tabular} & \begin{tabular}{|c|}
2007 \\
$J|F M A| M J J \mid A S S O N D$
\end{tabular} & \begin{tabular}{|l|l} 
JFIMAM \\
\end{tabular} \\
\hline 1 Phase 1 Predesign Evaluations & & & & & & & & \\
\hline 1.1 DOE Cooperative Agreement Executed & & & & & & & & \\
\hline 1.2 0.0 NEPA Review and Approval & & & ב & & & & & \\
\hline 1.3 1.1 Demonstration Site Selection & & & & & & & & \\
\hline 1.4 1.2 Gasification Island Design Study & & & & & & & & \\
\hline 1.5 1.3 Indirect Air Heater System Design Study & & & & & & & & \\
\hline 1.6 1.4 Stoker Boiler Modification Design Study & & & & & & & & \\
\hline 1.71.5 Power Island Design Study & & & & & & & & \\
\hline 1.81.6 Power Systems Integration Study & & & & & & & & \\
\hline 1.9 Finalize Demo System Configuration & & & $\mathbf{0}$ & & & & & \\
\hline 1.10 1.7 Capital and Operating Cost Study & & & 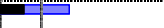 & & & & & \\
\hline 1.11 1.8 Phase 1 Project Management & & & & & & & & \\
\hline 1.12 Subcontracting & & & & & & & & \\
\hline 1.13 Host Site Agreement & & & & & & & & \\
\hline 1.14 Project Evaluation Report and Topical Report & & & $\mathbf{0}$ & & & & & \\
\hline 1.15 FPI Company and AF\&PA Endorsements & & & $\boldsymbol{0}$ & & & & & \\
\hline 1.16 AF\&PA Energy Performance Task Group Endor. & & & $\mathbf{0}$ & & & & & \\
\hline 1.17 Continuation Application & & & $\mathbf{0}$ & & & & & \\
\hline 2 DOE APPROVAL FOR PHASE 2 & & & $\mathbf{0}$ & & & & & \\
\hline 3 Phase 2 Demo Plant Design Development & & & & & & & & \\
\hline 3.1 2.1 Pilot Scale Verification & & & & & & & & \\
\hline 3.2 2.2 Detailed Engineering Design & & & & & & & & \\
\hline 3.3 2.3 Definitive Cost Estimate & & & & ᄃ & & & & \\
\hline 3.4 2.4 Phase 2 Project Management & & & & & & & & \\
\hline 3.5 Phase 2 Design and Cost Estimate Topical Repol & & & & $\mathbf{0}$ & & & & \\
\hline 4 DOE APPROVAL FOR PHASE 3 & & & & $\mathbf{0}$ & & & & \\
\hline 5 Phase 3 Procurement and Retrofit Construction & & & & & & & & \\
\hline 5.1 Place Long Lead Orders & & & & 0 & & & & \\
\hline 5.2 3.1 Retrofit Permitting Effort & & & & & & & & \\
\hline 5.3 3.2 Procure Major Equipment & & & & & $\square$ & & & \\
\hline 5.4 3.3 Construction \& Installation & & & & & & & & \\
\hline 5.5 3.4 Phase 3 Project Management & & & & & & & & \\
\hline 5.6 Phase 3 Procurement and Installation Topical $R e_{1}$ & & & & & & $\mathbf{0}$ & & \\
\hline 6 Phase 4 Demonstration Plant Operations & & & & & & & & \\
\hline 6.1 Commissioning and Startup Plan & & & & & & $\mathbf{0}$ & & \\
\hline 6.2 4.1 Plant Commissioning, Shakedown and Startu| & & & & & & 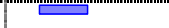 & & \\
\hline 6.3 Performance Testing Plan & & & & & & $\mathbf{0}$ & & \\
\hline 6.4 4.2 Performance Testing & & & & & & & & \\
\hline 6.5 Demonstration Operations Plan & & & & & & $\mathbf{0}$ & & \\
\hline 6.6 4.3 Demonstration Operations & & & & & & & & \\
\hline 6.7 Final Technical Project Demonstration Report & & & & & & & & $\mathbf{0}$ \\
\hline
\end{tabular}

